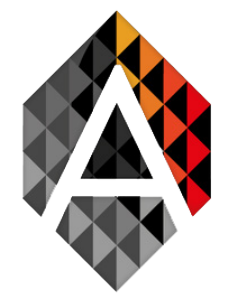

\title{
Kids' Atlas application to Learn about Geography and Maps
}

Nahla Aljojo ${ }^{a}$, Ameen Banjar ${ }^{\mathrm{a}}$, Mashael Khayyat ${ }^{\mathrm{a}}$, Basma Alharbi $^{\mathrm{b}}$, Areej Alshutayri ${ }^{\mathrm{b}}$, Amani Jamal ${ }^{\mathrm{c}}$, Azida Zainol ${ }^{\mathrm{d}}$, Dana Waggas ${ }^{\mathrm{a}}$, Ghydaa Saleh ${ }^{\mathrm{a}}$, Rahaf Alshehria and Shoroug Aljuaid ${ }^{\mathrm{a}}$

a College of Computer Science and Engineering, Department of Information Systems and Technology, University of Jeddah, Jeddah, Saudi Arabia

b College of Computer Science and Engineering, Department of Computer Science and Artificial Intelligence, University of Jeddah, Jeddah, Saudi Arabia

c Faculty Computing \&Information technology, Computer Science Department, King Abdul Aziz University, Jeddah, Saudi Arabia

d University of Jeddah, College of Computer Science and Engineering, Department of Software Engineering, Jeddah, Saudi Arabia

nmaljojo@uj.edu.sa, abanjar@uj.edu.sa, mkhayyat@uj.edu.sa, bmalharbi@uj.edu.sa, aoalshutayri@uj.edu.sa, atjamal@kau.edu.sa, azzainol@uj.edu.sa

\section{KEYWORD ABSTRACT}

Kids'Atlas;

voice recognition; $3 D$ items learning
Studies of the world's geography have grown together with human developments and revolutions. Atlases often present geographic features and boundaries of areas; an atlas is a compilation of different Earth maps or Earth regions. Most teachers still use classical methods of teaching. Geographical concepts and map-reading skills are the most common aspects of learning that early-stage students find challenging. Hence, the objective of this study is to develop a geography application for children between the ages of 9 and 12 years that would allow them to learn maps. Thus, Kids' Atlas is an android application, which is to help children to learn easily and test their knowledge. The application improves learning through entertainment by adding technologies that will help children to learning geography by capturing their attention to learn by visualizing objects and allows them to interact more effectively than traditional methods teaching by visualizing the $3 D$ items. The methodology involves a set
Nahla Aljojo, Ameen Banjar, Mashael Khayyat, Basma Alharbi, Areej Alshutayri, Amani Jamal, Azida Zainol, Dana Waggas, Ghydaa Saleh, Rahaf Alshehri and Shoroug Aljuaid Kids' Atlas application to Learn about

Geography and Maps
ADCAIJ: Advances in Distributed Computing and Artificial Intelligence Journal Regular Issue, Vol. 9 N. 2 (2020), 33-48 eISSN: 2255-2863 - https://adcaij.usal.es Ediciones Universidad de Salamanca - CC BY-NC-ND 
of software development phases, beginning with the planning; analyze data, design, implementation, testing and maintenance phases. The result has shown positive indicators that improve children's ability and knowledge of geography. This study contributes to the growth of education in early childhood, which is essential to shape the nation for the future. Therefore, this project is significant and relevant, as it contributes to the knowledge society for Saudi Arabia.

\section{Introduction}

Education is essential for the future of all, and providing quality education will make it easier for learners to understand a topic. The first thing most individuals will do when faced with an issue of understanding their subject is to use technology to attempt different techniques to explain the topic they want to comprehend or know more about; they will look for fun learning techniques, especially if the learners are children.

Most teachers still use classical methods of teaching. Geography concepts and map-reading skills are the most common aspects of learning that early-stage students have difficulties, with which they will suffer in the future (GÖKÇE, 2009). Furthermore, secondary school geography teachers do not have adequate skills to manage and teach their classes effectively. This has an adverse effect upon the students, limiting their ability to concentrate on the lessons; they are unlikely to consider the subject interesting or enjoyable (Kaya, 2018). As we understand these problems in teaching geography, an application known as "Kid's Atlas" is developed to help children enjoy geographical maps and make it easier for them to remember. The Kid's Atlas provides these features:

- Helps children learn and enjoy geography in a fun way

- Allows children to know about important information about the world, including the countries of the world and their flags.

- Allows children to see 3D items related to the maps.

- The app comes with two modes:

- Learning mode: learn the countries and flags of the world

- Quiz mode: practice the information covered.

The main aim of this project is to describe and assess some of the methods that are used to teach geography. To improve the learning process, we provide some features in the application that can help children, especially students, learn effortlessly. Moreover, the application can meet the various needs of the children in entertaining ways.

The primary objective of this project is to suggest a geography application for children between the ages of 9 and 12 years that would allow them to learn maps. Thus, the application will:

- Improve learning through entertainment by adding technologies that will help children to learn geography.

- Capture children's attention by using visual objects.

- Make children interact more effectively by using 3D items.

- Improve the individual's knowledge by providing a training section that contains simple quizzes.

Nahla Aljojo, Ameen Banjar, Mashael Khayyat, Basma Alharbi, Areej Alshutayri, Amani Jamal, Azida Zainol, Dana Waggas, Ghydaa Saleh, Rahaf Alshehri and Shoroug Aljuaid Kids' Atlas application to Learn about

Geography and Maps
ADCAIJ: Advances in Distributed Computing and Artificial Intelligence Journal Regular Issue, Vol. 9 N. 2 (2020), 33-48 eISSN: 2255-2863 - https://adcaij.usal.es Ediciones Universidad de Salamanca - CC BY-NC-ND 
- Provide listening/voice recognition capability for information countries.

- The ability to search for a country by voice recognition and zooming for searched country.

- The scope of the project is to develop a geography application using 3D items to teach children about different countries and important information about them; it also includes a test to assess the children's learning.

The paper is arranged in the following sequences which discuss the introduction in section 1, the background of the study in section 2, the methodology in section 3, the result and analysis in section 4 and finally section 5 explains the conclusion and future work.

\section{Background}

Nowadays, technology plays a major role in various aspects of people's lives, such as manufacturing, education, and health, and so on. Usually, people use technology to make certain things simpler, such as reading, communication and entertainment. Mobile apps have recently become the most commonly used technology. As the use of mobile apps increases, the number of apps generated also increases (Prensky, 2002).

\subsection{Education in Saudi Arabia}

The Kingdom of Saudi Arabia places great significance on education because it is considered to transform future generations, who are the true wealth of the country. Education, in particular, is a process of changing and transformation that should continue and not stop at some point. The demands of change are part of this process, as life continues to change (Alnahdi, 2014).

Essentially, just as you need to know the alphabet for learning, and multiplication tables for arithmetic, you also need to study geography to know where different locations are sited and learn some information about those places so you can say why they are different.

Being surrounded by water or being in the middle of a desert will have a drastic impact on the ideals of a society and on how they live their daily lives. Once children learn geography from around the world, they will be able to gain more knowledge for other countries and cultures ("Top 10 Reasons to Study Geography", 2019).

\subsection{Related Work}

This section discusses four applications which are related to geography and atlas for further understanding.

\subsubsection{Wonder Earth ("Wonder Earth", 2019)}

This app provides an interactive 3D globe. This app allows children to use their mobile devices to discover the world's wonders and its beauty quickly. Wonder Earth is an interactive 3D globe developed by the Playtech Studio in Singapore. It describes the most interesting facts of each country in simple and concise language; it provides interesting facts about more than 170 countries and their flags. Also, it enables users to highlight countries, provides background music and it supports five languages.

Nahla Aljojo, Ameen Banjar, Mashael Khayyat, Basma Alharbi, Areej Alshutayri, Amani Jamal, Azida Zainol, Dana Waggas, Ghydaa Saleh, Rahaf Alshehri and Shoroug Aljuaid Kids' Atlas application to Learn about

Geography and Maps
ADCAIJ: Advances in Distributed Computing and Artificial Intelligence Journal Regular Issue, Vol. 9 N. 2 (2020), 33-48 eISSN: 2255-2863 - https://adcaij.usal.es Ediciones Universidad de Salamanca - CC BY-NC-ND 


\subsubsection{World map ("World Map Challenge! Geography", 2015)}

World map is an application that is available on IOS devices for preschool and primary school children. This application helps students to get a better understanding of the concepts that in the app. The application provides tools that help the user to determine the right place in the map. By touching the country in the map and it will show whether the answer is true or false. The World Map Challenge helps the children to challenge their world geography skills, letting them learn locations around the globe from nearly 200 countries.

\subsubsection{Barefoot world atlas ("Barefoot World Atlas Review for Teachers", 2019)}

Users can discover their own countries and regions, learning about their surroundings, and what makes them unique.The Barefoot World Atlas software is an immersive 3D encyclopedic globe created in collaboration with Touch Press by Barefoot Books.

This encourages children to embark on an exciting and informative journey by discovering interesting facts about the world's regions and countries and immersing themselves in our planet's diverse cultures and natural beauty. Children can compare their lives quickly and easily with other people's experiences

\subsubsection{Planet Geo ("Planet Geo - geography games for kids \& teenagers", 2019)}

Teachers can use Planet Geo for individual lessons on world geography and for classes for children. With eight language options, Planet Geo can also be a great geography app for multilingual children or ELL learners, or in a world language class. Planet Geo geography games for children and adolescents is a game and data device that measures children's knowledge of many countries, hundreds of towns, and the UNESCO World Heritage Sites.

This application has maps, information about the locations, and fun images inspire the geography games and can attract the attention of children by turning names and places into places where fascinating things have happened. In addition, the application also allows choosing a country or continent puzzle (easy or difficult level), a matching country-to-continent game, a "geo book" that gives lots of details about a country or city, or locator games for World Heritage Site.

\subsection{Comparison of Applications}

This section explores the differences between applications. See Table 1.

Table 1: Comparison of atlas applications

\begin{tabular}{|l|l|l|}
\hline \multicolumn{1}{|c|}{ Name } & \multicolumn{1}{|c|}{ Tools/Technique } & \multicolumn{1}{c|}{ Objectives } \\
\hline $\begin{array}{l}\text { Wonder Earth ("Won- } \\
\text { der Earth", 2019) }\end{array}$ & $\begin{array}{l}\text { - 3D objects } \\
\text { - Voice instructions }\end{array}$ & $\begin{array}{l}\text { - Provides interesting facts about more } \\
\text { than } 170 \text { countries. }\end{array}$ \\
IOS & - Zoom and rotate the Earth & $\begin{array}{l}\text { Application can be used anywhere and } \\
\text { works with or without Wi-Fi. } \\
\text { - Provides information about influential } \\
\text { people in history. }\end{array}$ \\
\hline
\end{tabular}

Nahla Aljojo, Ameen Banjar, Mashael Khayyat, Basma Alharbi, Areej Alshutayri, Amani Jamal, Azida Zainol, Dana Waggas, Ghydaa Saleh, Rahaf Alshehri and Shoroug Aljuaid Kids' Atlas application to Learn about

Geography and Maps
ADCAIJ: Advances in Distributed Computing and Artificial Intelligence Journal Regular Issue, Vol. 9 N. 2 (2020), 33-48 eISSN: 2255-2863 - https://adcaij.usal.es Ediciones Universidad de Salamanca - CC BY-NC-ND 


\begin{tabular}{|c|c|c|}
\hline Name & Tools/Technique & Objectives \\
\hline $\begin{array}{l}\text { World Map ("World } \\
\text { Map Challenge! Ge- } \\
\text { ography", 2015) } \\
\text { Europe and Asia } \\
\text { IOS }\end{array}$ & $\begin{array}{l}\text { - Voice instructions. } \\
\text { - Fully interactive map }\end{array}$ & $\begin{array}{l}\text { - Complete interactive map (zoom, pan } \\
\text { and tap on the map) with sound effects. } \\
\text { "Continental Challenge" mode: If the } \\
\text { player scores high enough, it records } \\
\text { their progress to win stars. } \\
\text { - Incorrect answers will cause the map to } \\
\text { zoom in to the correct location, making } \\
\text { quick and efficient learning. }\end{array}$ \\
\hline $\begin{array}{l}\text { Barefoot World Atlas } \\
\text { ("Barefoot World At- } \\
\text { las Review for Teach- } \\
\text { ers", 2019) } \\
\text { USA } \\
\text { IOS }\end{array}$ & $\begin{array}{l}\text { - Animated 3-D globe } \\
\text { - Zoom in on objects }\end{array}$ & $\begin{array}{l}\text { - Children can compare their lives quick- } \\
\text { ly and easily with other people's expe- } \\
\text { riences. } \\
\text { - Every child can travel around, explor- } \\
\text { ing the rich wonders of our world with } \\
\text { this amazing app. } \\
\text { - It invites children to embark on a thrill- } \\
\text { ing and informative journey as they ex- } \\
\text { plore the fascinating facts of an area or } \\
\text { country. }\end{array}$ \\
\hline $\begin{array}{l}\text { Planet Geo ("Plan- } \\
\text { et Geo - geography } \\
\text { games for kids \& } \\
\text { teenagers", 2019) } \\
\text { IOS }\end{array}$ & $\begin{array}{l}\text { - Voice instructions } \\
\text { - Display visual elements }\end{array}$ & $\begin{array}{l}\text { - Engaging colorful maps. } \\
\text { - Several types of activities allow chil- } \\
\text { dren multiple ways to enter the content. } \\
\text { - Written information about UNESCO } \\
\text { World Heritage sites and the pictures } \\
\text { that accompany them enliven the sim- } \\
\text { ple geographical games. }\end{array}$ \\
\hline $\begin{array}{l}\text { Kids Atlas } \\
(2019-2020) \\
\text { KSA } \\
\text { Android }\end{array}$ & $\begin{array}{l}\text { - 3D objects } \\
\text { - Voice instructions } \\
\text { - Voice recognition } \\
\text { - Zoom and rotate the Earth }\end{array}$ & $\begin{array}{l}\text { - Capture children's attention to learning } \\
\text { by visualizing objects. } \\
\text { - Make children interact more effective- } \\
\text { ly by seeing the 3D items. } \\
\text { - Improve the individual's ability to un- } \\
\text { derstand by provide a training section } \\
\text { containing simple quizzes. } \\
\text { - Provide listening/voice recognition ca- } \\
\text { pability for information countries. } \\
\text { - The ability to search for a country by } \\
\text { voice recognition and zooming. }\end{array}$ \\
\hline
\end{tabular}

\section{Methodology}

The method for developing the Kid's Atlas consists of four stages as outlined below.

Nahla Aljojo, Ameen Banjar, Mashael Khayyat, Basma Alharbi, Areej Alshutayri, Amani Jamal, Azida Zainol, Dana Waggas, Ghydaa Saleh, Rahaf Alshehri and Shoroug Aljuaid Kids' Atlas application to Learn about

Geography and Maps
ADCAIJ: Advances in Distributed Computing and Artificial Intelligence Journal Regular Issue, Vol. 9 N. 2 (2020), 33-48 eISSN: 2255-2863 - https://adcaij.usal.es Ediciones Universidad de Salamanca - CC BY-NC-ND 


\subsection{Stage 1: Analysis}

In this stage, we conducted the data collection, data analysis and requirements analysis using Unified Modeling Language.

\subsubsection{Data Collection}

The data collection was conducted using an online survey designed for teachers and parents. The Google Form questionnaire had 10 questions ("Google Forms: Online Form Builder for Business I G Suite", 2019). The survey was distributed to teachers and parents through group messages.

The survey focused on collecting data from teachers and parents about the use of technology in the learning process to estimate how effective our Kids' Atlas application would be. The total number of responses was 215 , of which 127 were from parents and 88 were from teachers.

\subsubsection{Functional Requirements}

System function describes what the system should do (Pressman \& Maxim, 2015), functional requirements considers the behavior of the system under particular conditions (Ian, 2016). For the application to be functional, users need to be able to do the following:

- Allow user to enter username.

- Allow user to select a section to learn about, search for a country by voice recognition and by touch to see 3D items related to the maps and see the country flags.

- Allow user to select quiz section and answer questions.

- Allow admin to manage the content by upgrading the application if it needs updates, or editing.

\subsubsection{Non-Functional Requirements}

Non-functional requirements determine how the system works (Pressman \& Maxim, 2015); that is, how the system performs and what restricts its functionality (Ian, 2016). The following are deemed essential non-functional requirements:

- Usability: Simple for users to understand, effective for learning, user friendly and easy to use.

- Accessibility: Easy for people with different capabilities to use, to navigate between pages and flexible for all people to use.

- Performance: The application's ability to provide fast response time, when the user loads and refreshes the application.

\subsubsection{Hardware and Software Requirements}

To develop the application, we used laptops, desktop computers and smart phones that access Google play store. The application's code was written using $\mathrm{C \#}$ and $\mathrm{C}++$ programming languages. The pre-existing programs used to implement the application were as follows:

- Visual Studio 2017: This program is invaluable to game developers, as it facilitates real time 2D, 3D, and AR interactive experiences and visualizations to be developed.

- 3D Max (“3D Max”, 2019): is the application to provide 3D computer graphics software for 3D animations, models, games and pictures

Nahla Aljojo, Ameen Banjar, Mashael Khayyat, Basma Alharbi, Areej Alshutayri, Amani Jamal, Azida Zainol, Dana Waggas, Ghydaa Saleh, Rahaf Alshehri and Shoroug Aljuaid Kids' Atlas application to Learn about

Geography and Maps
ADCAIJ: Advances in Distributed Computing and Artificial Intelligence Journal Regular Issue, Vol. 9 N. 2 (2020), 33-48 eISSN: 2255-2863 - https://adcaij.usal.es Ediciones Universidad de Salamanca - CC BY-NC-ND 
- Adobe Illustrator ("Adobe Illustrator", 2019): is an application for producing a wide range of digital and printed objects, including comics, maps, diagrams, graphs, logos and illustrations.

\subsection{Stage 2: Design}

In the design stage, which helps to understand the requirements delivered by the analysis, phase, the requirements are transferred into an architecture chart. This architecture chart determines the components, their interfaces, and behaviors. Also, it helps to determine how to build the best solution. In this phase, we will also develop the prototypes ("Design Phase - ZMQ Development", 2019). The purpose of the design phase to construct the interface to enable the user to run the system and its functions (Maryland, 2009).

\subsubsection{Prototype Design}

A prototype is the preliminary model, form or an instance of something that then becomes the basis for future developments. Software prototypes observe this definition and purpose, being the working example from which advancements are made to obtain a new model or a new version. Having a prototype provides developers and the implementers with the opportunity to expose the model to evaluation and get user feedback and using that to refine the model before committing to the actual project (Arnowitz et al., 2007).

\subsubsection{Designing Low Fidelity prototype}

The low fidelity prototype design illustrated in Figure 1, is a simplified representation of the product and design concepts. It is the basis from which the design ideas are transformed into testable and tangible things. Such a prototype enables the user's requirements to be collected and analyzed early on in the project's development (Tiong et al., 2018).

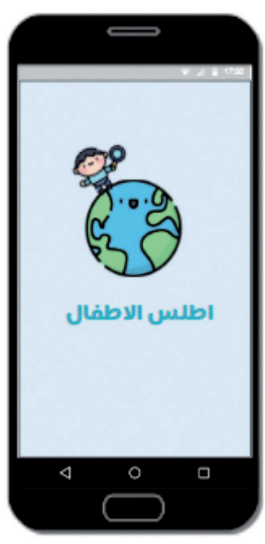

A

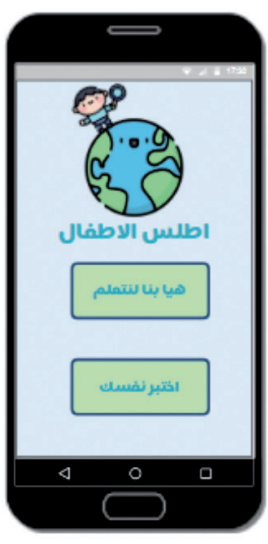

B

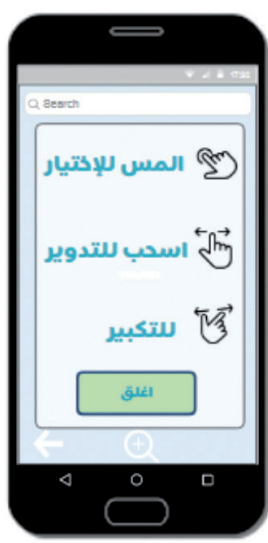

$\mathrm{C}$

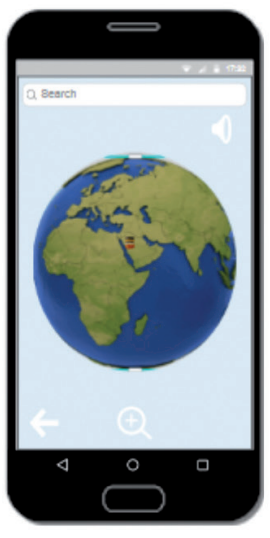

D

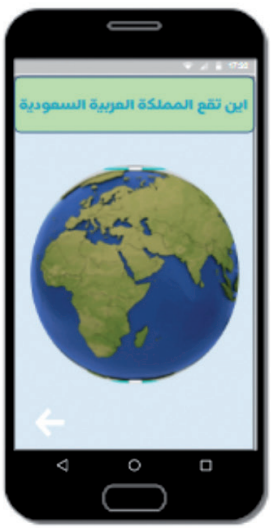

$\mathrm{E}$

Figure 1: high fidelity prototype A) First screen shows the logo and name of application;

$B$ ) Home screen contain learning button and quiz button C) Instruction screen D) 3D world map E) Quiz screen.

Nahla Aljojo, Ameen Banjar, Mashael Khayyat, Basma Alharbi, Areej Alshutayri, Amani Jamal, Azida Zainol, Dana Waggas, Ghydaa Saleh, Rahaf Alshehri and Shoroug Aljuaid Kids' Atlas application to Learn about

Geography and Maps
ADCAIJ: Advances in Distributed Computing and Artificial Intelligence Journal Regular Issue, Vol. 9 N. 2 (2020), 33-48 eISSN: 2255-2863 - https://adcaij.usal.es Ediciones Universidad de Salamanca - CC BY-NC-ND 


\subsubsection{Designing High Fidelity Prototype}

High-fidelity prototypes give users an indication of what the final interface product will look and feel. Prototypes help to identify problems and their potential solutions (Tiong et al., 2018).

\subsubsection{Database Design}

A database is a collection of data, which are known facts with inherent meaning that can be recorded. Sometimes known as the Universe of Discourse (UoD) because they characterize various aspects of the real world, databases are a collection of data. Databases are populated with particular data, which is collected to fulfill a particular function; the design and build of the database needs to match the function (Elmasri \& Navathe, 2010). Here, we devised a logical database design and physical database design.

\subsubsection{User Interface Design}

The purpose of the user interface design is to assist users who are building the application to implement easy to use features and other design requirements. (Shneiderman et al., 2016). The following user interface principles were applied to this application (Ambler, 2014):

- The structure principle:

The user interface design should be organized based on clear and consistent models that are recognizable to users.

- The simplicity principle:

The design must be effective, enabling common tasks to be undertaken easily and have good shortcuts. These need to be clear and meaningful in the user's language.

- The visibility principle:

All the essential materials and options need to be visible, but not obtrusive, and users should not be distracted by unnecessary information. Effective designs are simple and straightforward to use; they should only provide the information users need to operate the application.

- The feedback principle:

The design should use familiar and concise language to inform users about the application's actions, status changes, and user errors or exceptions.

- The reuse principle:

To minimize the user's need to remember things, the design must adopt internal and external behaviors and components that are already familiar to users.

\subsection{Stage 3: Implementation}

We set up an external database to which we connected the application via the SQL Server. This dictated the Android Studio program be used for the design and development of the application. We utilized the SQLite database, which is a local, file-based database. This enables us to store our app's data, like quiz questions and sound links about country's information, the player's name and his records, and monument names that are linked to a specific country. Furthermore, we used Unity, 3D

Nahla Aljojo, Ameen Banjar, Mashael Khayyat, Basma Alharbi, Areej Alshutayri, Amani Jamal, Azida Zainol, Dana Waggas, Ghydaa Saleh, Rahaf Alshehri and Shoroug Aljuaid Kids' Atlas application to Learn about

Geography and Maps
ADCAIJ: Advances in Distributed Computing and Artificial Intelligence Journal Regular Issue, Vol. 9 N. 2 (2020), 33-48 eISSN: 2255-2863 - https://adcaij.usal.es Ediciones Universidad de Salamanca - CC BY-NC-ND 
Max, and Photoshop to design the pictures. The application consists of five primary sections as describe in Figure 2:

- First screen shows the logo and name of application.

- Home screen contain learning button and quiz button.

- Instruction screen.

- 3d world map.

- Quiz screen.
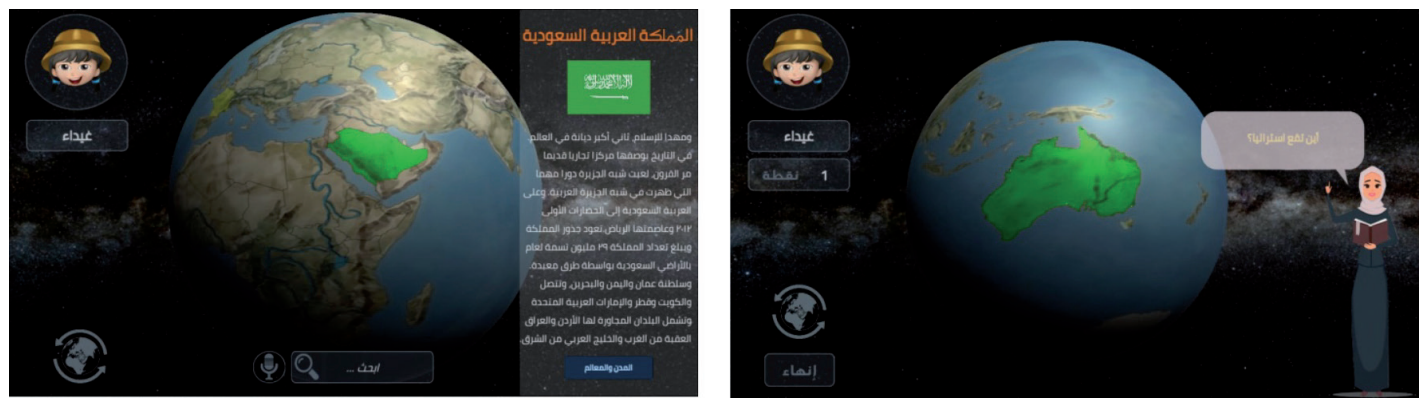

Figure 2: Application interfaces.

\subsection{Stage 4: Testing}

\subsubsection{Unit testing}

Unit Testing is a software testing method in which individual software units, i.e. a group of computer system modules, installation procedures and operating procedures, are tested to determine whether they are suitable for use (Ammann \& Offutt, 2016).

The third test calculates the user's score if the user chooses the "True" answer, will continue to the next question. If the user chooses "False" answer, it will move to the next question as shown in Table 2.

Table 2: Unit Testing

\begin{tabular}{|c|c|c|c|}
\hline Functionality & Input & Expected result & Actual result \\
\hline \multirow{3}{*}{ Insert user name } & Dana & Successful & Pass \\
\hline & "دانة" & Successful & Pass \\
\hline & No input entered & Failed & Pass \\
\hline \multirow{2}{*}{ Search for country } & " المملكة العربية السعودية “، & Successful & Pass \\
\hline & Saudi Arabia & Failed & Pass \\
\hline \multirow{2}{*}{ Calculate score } & True answer, next question & Successful & Pass \\
\hline & False answer, next question & Successful & Pass \\
\hline
\end{tabular}

Nahla Aljojo, Ameen Banjar, Mashael Khayyat, Basma Alharbi, Areej Alshutayri, Amani Jamal, Azida Zainol, Dana Waggas, Ghydaa Saleh, Rahaf Alshehri and Shoroug Aljuaid Kids' Atlas application to Learn about

Geography and Maps
ADCAIJ: Advances in Distributed Computing and Artificial Intelligence Journal Regular Issue, Vol. 9 N. 2 (2020), 33-48 eISSN: 2255-2863 - https://adcaij.usal.es Ediciones Universidad de Salamanca - CC BY-NC-ND 


\subsubsection{Integration Testing}

This is defined as form of test where the software modules are logically integrated and tested as a group. A typical software project is made up of several software modules programmed by various programmers. The aim of this test level is to reveal defects in the interaction between these software modules when integrated in this part we will test the app integration and how each part integrates with other part in the app, as shown in Table 3.

Table 3: Integration testing

\begin{tabular}{|l|c|}
\hline \multicolumn{1}{|c|}{ Test scenarios } & Result \\
\hline If a user enters his name, the name will appear in all pages. & Pass \\
\hline If a user ends his test, the score should be updated and displayed in the user's profile. & Pass \\
\hline $\begin{array}{l}\text { If the user clicks on a country, its name, flag, most important information and features } \\
\text { will be voice displayed. }\end{array}$ & Pass \\
\hline
\end{tabular}

\subsubsection{Compatibility Testing}

Compatibility testing is a form of software program testing used to make sure the system works with many different objects such as internet browsers, hardware platforms, users, operating systems, etc. Our application named "Kids' Atlas" will be tested to make sure its compatible with three different devices as shown in Table 4.

Table 4: Compatibility Testing

\begin{tabular}{|c|c|c|c|}
\hline Test & \multicolumn{3}{|c|}{ Device } \\
\hline Operating systems & Android & Android & Android \\
\hline Type & Galaxy S8+ & Huawei P30 & Galaxy tablet A \\
\hline Memory space & $64 \mathrm{~GB}$ & $128 \mathrm{~GB}$ & $32 \mathrm{~GB}$ \\
\hline Screen resolution & Compatible & Compatible & Compatible \\
\hline Pass/Fail & Pass & Pass & Pass \\
\hline
\end{tabular}

\subsubsection{System Testing Using Usability Testing}

Usability testing refers to testing the product from the users' perspectives, to make sure that the user understands everything in the system, and to measure how easy it is to use. We tested the usability of the Kids Atlas app functions using (Whitehead, 2006) recounts McLaughin and Skinner's principles (Mclaughlin \& Skinner, 2000) to determining the usability of the application's criteria, of which there are six. The questionnaire was developed using six questions using Google Forms. The survey was distributed to our families; we gave them the application and after they used it, they answered the questionnaire. The questionnaire focused on the application from several directions, how it was used, and its ease of use. The total number of responses was 100. See Table 5.

Nahla Aljojo, Ameen Banjar, Mashael Khayyat, Basma Alharbi, Areej Alshutayri, Amani Jamal, Azida Zainol, Dana Waggas, Ghydaa Saleh, Rahaf Alshehri and Shoroug Aljuaid Kids' Atlas application to Learn about

Geography and Maps
ADCAIJ: Advances in Distributed Computing and Artificial Intelligence Journal Regular Issue, Vol. 9 N. 2 (2020), 33-48 elSSN: 2255-2863 - https://adcaij.usal.es Ediciones Universidad de Salamanca - CC BY-NC-ND 
Table 5: Whitehead (2006) recounts McLaughin and Skinner's principles

for determining the usability of the application

\begin{tabular}{|l|c|c|c|c|c|}
\hline \multicolumn{1}{|c|}{ Measure } & $\begin{array}{c}\text { Strongly } \\
\text { Agree }\end{array}$ & Agree & Disagree & $\begin{array}{c}\text { Strongly } \\
\text { Disagree }\end{array}$ & $\begin{array}{c}\text { No } \\
\text { Opinion }\end{array}$ \\
\hline $\begin{array}{l}\text { Checkability: To ensure the right informa- } \\
\text { tion is entering and leaving the system, it } \\
\text { must have the inspection facility. }\end{array}$ & $61.9 \%$ & $38.1 \%$ & 0 & 0 & 0 \\
\hline $\begin{array}{l}\text { Confidence: Users need to feel confident } \\
\text { about the system and their ability to use it. }\end{array}$ & $66.7 \%$ & $33.3 \%$ & 0 & 0 & 0 \\
\hline $\begin{array}{l}\text { Control: Users are able to regulate the sys- } \\
\text { tem, and the information that enters and ex- } \\
\text { its it in particular. }\end{array}$ & $66.7 \%$ & $33.3 \%$ & 0 & 0 & 0 \\
\hline $\begin{array}{l}\text { Ease of Use: Users find the system easy to } \\
\text { operate. }\end{array}$ & $61.9 \%$ & $38.1 \%$ & 0 & 0 & 0 \\
\hline $\begin{array}{l}\text { Speed: The system responds rapidly. } \\
\text { Understanding: Users can understand the } \\
\text { system and its outputs. }\end{array}$ & $61.9 \%$ & $38.1 \%$ & 0 & 0 & 0 \\
\hline
\end{tabular}

\section{Result Analysis and Discussions}

The results of the online survey that was conducted for this project are presented here. Analyzing this information helps us understand user's requirements for the Kids' Atlas application. Table 6 shows that of the respondents of teachers and Table 7 show that of the respondents of parents.

Table 6: The Distribution of demographic data in the study group of teachers $(n=88)$

\begin{tabular}{|c|c|c|}
\hline & N & $\%$ \\
\hline Distribution of the participants (teachers) & According to gender \\
\hline Female & 56 & 64 \\
\hline Male & 32 & 36 \\
\hline Total & 88 & 100 \\
\hline Distribution the participants (teachers) & According to the age \\
\hline $23-27$ & 9 & 10. \\
\hline $28-32$ & 9 & 10 \\
\hline $33-42$ & 27 & 31 \\
\hline $43-47$ & 14 & 16 \\
\hline More than 47 & 29 & 33 \\
\hline
\end{tabular}

Nahla Aljojo, Ameen Banjar, Mashael Khayyat, Basma Alharbi, Areej Alshutayri, Amani Jamal, Azida Zainol, Dana Waggas, Ghydaa Saleh, Rahaf Alshehri and Shoroug Aljuaid Kids' Atlas application to Learn about

Geography and Maps
ADCAIJ: Advances in Distributed Computing and Artificial Intelligence Journal Regular Issue, Vol. 9 N. 2 (2020), 33-48 elSSN: 2255-2863 - https://adcaij.usal.es Ediciones Universidad de Salamanca - CC BY-NC-ND 


\begin{tabular}{|c|c|c|}
\hline & N & $\%$ \\
\hline Distribution the participants (teachers) & According to the education \\
\hline Bachelor's & 67 & 76 \\
\hline Master's & 8 & 9. \\
\hline PhD. & 0 & 0 \\
\hline Other & 13 & 15 \\
\hline
\end{tabular}

Table 7: The Distribution of demographic data in the study group of parents $(n=127)$

\begin{tabular}{|c|c|c|}
\hline & $\mathrm{N}$ & $\%$ \\
\hline \multicolumn{3}{|c|}{ Distribution of the participants (parents) According to Gender } \\
\hline Female & 89 & 70 \\
\hline Male & 38 & 30 \\
\hline Total & 127 & 100 \\
\hline \multicolumn{3}{|c|}{ Distribution the participants (parents) According to the age } \\
\hline $18-22$ & 8 & 6. \\
\hline $23-27$ & 19 & 15 \\
\hline $28-32$ & 15 & 12 \\
\hline $33-42$ & 41 & 32 \\
\hline $43-47$ & 18 & 14 \\
\hline More than 47 & 26 & 21 \\
\hline \multicolumn{3}{|c|}{ Distribution the participants (parents) According to the education } \\
\hline Bachelor & 74 & 58 \\
\hline Master & 13 & 10 \\
\hline Ph.D. & 2 & 2 \\
\hline Other & 38 & 30 \\
\hline \multicolumn{3}{|c|}{ Distribution the participants (parents) According to the job } \\
\hline Student & 14 & 11 \\
\hline Teacher & 8 & 6 \\
\hline House wife & 52 & 41 \\
\hline Other & 52 & 41 \\
\hline
\end{tabular}

Nahla Aljojo, Ameen Banjar, Mashael Khayyat, Basma Alharbi, Areej Alshutayri, Amani Jamal, Azida Zainol, Dana Waggas, Ghydaa Saleh, Rahaf Alshehri and Shoroug Aljuaid Kids' Atlas application to Learn about

Geography and Maps
ADCAIJ: Advances in Distributed Computing and Artificial Intelligence Journal Regular Issue, Vol. 9 N. 2 (2020), 33-48 eISSN: 2255-2863 - https://adcaij.usal.es Ediciones Universidad de Salamanca - CC BY-NC-ND 
The data shown in Table 8 are the teachers' opinions on the use of technology, such as three-dimensional lessons, particularly for geography. We also asked them if they had any suggestions about our application that they would like to apply. Most of the responses related to the use of technology to help teachers in the teaching process and improve the skills of students.

Table 8: Ranking Analysis of the Likert-Type Scale (Teachers'answers) (N=88)

\begin{tabular}{|c|c|c|c|c|c|c|}
\hline \multicolumn{1}{c|}{ Questions } & $\begin{array}{c}\text { Strongly } \\
\text { agree } \\
\%\end{array}$ & $\begin{array}{c}\text { Agree } \\
\%\end{array}$ & $\begin{array}{c}\text { Neutral } \\
\%\end{array}$ & $\begin{array}{c}\text { Disagree } \\
\%\end{array}$ & $\begin{array}{c}\text { Strongly } \\
\text { disagree } \\
\%\end{array}$ & Attitude \\
\hline $\begin{array}{l}\text { 1. I support the impor- } \\
\text { tance of educating chil- } \\
\text { dren via mobile apps }\end{array}$ & 9.1 & 39.8 & 29.5 & 12.5 & 9.1 & Agree \\
\hline $\begin{array}{l}\text { 2. The integration of edu- } \\
\text { cation with technology } \\
\text { will positively affect the } \\
\text { child's education }\end{array}$ & 22.7 & 51.1 & 12.5 & 11.4 & 2.3 & Agree \\
\hline $\begin{array}{l}\text { 3. I support the use of the } \\
\text { application to illustrate } \\
\text { the most important fea- } \\
\text { tures of the countries } \\
\text { using maps of each } \\
\text { country through the use } \\
\text { of three-dimensional } \\
\text { technology }\end{array}$ & 39.8 & 43.2 & 5.7 & 6.8 & 4.5 & Agree \\
\hline $\begin{array}{l}\text { 4. The app will help devel- } \\
\text { op the child's self-learn- } \\
\text { ing ability in education }\end{array}$ & 33 & 45.5 & 12.5 & 6.8 & 2.3 & Agree \\
\hline $\begin{array}{l}\text { 5. I support the use of self- } \\
\text { test feature of the child } \\
\text { through the application } \\
\text { to identify the map of } \\
\text { each state }\end{array}$ & 34.1 & 45.5 & 8 & 8.5 & & \\
\hline
\end{tabular}

The data shown in Table 9 are the parents' opinions on the use of technology, such as three-dimensional teaching, particularly for geography. We also asked them if they had any feedback about our application that they would like to add. Most of the answers related to using technology to add fun to the teaching process to engage and increase the students' excitement.

Nahla Aljojo, Ameen Banjar, Mashael Khayyat, Basma Alharbi, Areej Alshutayri, Amani Jamal, Azida Zainol, Dana Waggas, Ghydaa Saleh, Rahaf Alshehri and Shoroug Aljuaid Kids' Atlas application to Learn about

Geography and Maps
ADCAIJ: Advances in Distributed Computing and Artificial Intelligence Journal Regular Issue, Vol. 9 N. 2 (2020), 33-48 eISSN: 2255-2863 - https://adcaij.usal.es Ediciones Universidad de Salamanca - CC BY-NC-ND 
Table 9: Ranking Analysis of the Likert-Type Scale (parents'answers) $(N=127)$

\begin{tabular}{|l|c|c|c|c|c|}
\hline \multicolumn{1}{|c|}{ Questions } & $\begin{array}{c}\text { Strongly } \\
\text { agree \% }\end{array}$ & $\begin{array}{c}\text { Agree } \\
\text { \% }\end{array}$ & $\begin{array}{c}\text { Neutral } \\
\text { \% }\end{array}$ & $\begin{array}{c}\text { Disagree } \\
\%\end{array}$ & $\begin{array}{c}\text { Strongly } \\
\text { disagree } \\
\%\end{array}$ \\
\hline $\begin{array}{l}\text { 1. I support the importance of edu- } \\
\text { cating children via mobile apps }\end{array}$ & 11 & 36.2 & 27.6 & 10.2 & 15 \\
\hline $\begin{array}{l}\text { 2. The integration of education with } \\
\text { technology will positively affect } \\
\text { the child's education }\end{array}$ & 18.1 & 51.2 & 11.8 & 9.4 & 9.4 \\
\hline $\begin{array}{l}\text { 3. I support the use of the application } \\
\text { illustrates the most important fea- } \\
\text { tures of the countries using maps } \\
\text { of each country through the use of } \\
\text { three-dimensional technology }\end{array}$ & 32.3 & 48.8 & 8.7 & 1.6 & 8.7 \\
\hline $\begin{array}{l}\text { 4. The app will help develop the } \\
\text { child's self-learning ability in ed- } \\
\text { ucation }\end{array}$ & 22.8 & 48 & 18.9 & 5.5 & 4.7 \\
\hline $\begin{array}{l}\text { 5. I support the use of self-test fea- } \\
\text { ture of the child through the appli- } \\
\text { cation to identify the map of each } \\
\text { state }\end{array}$ & 22 & 51.2 & 14.2 & 6.3 & 6.3 \\
\hline
\end{tabular}

The result of this project is a geographical application that assists children in learning geography. The interfaces are shown in Figure 3.
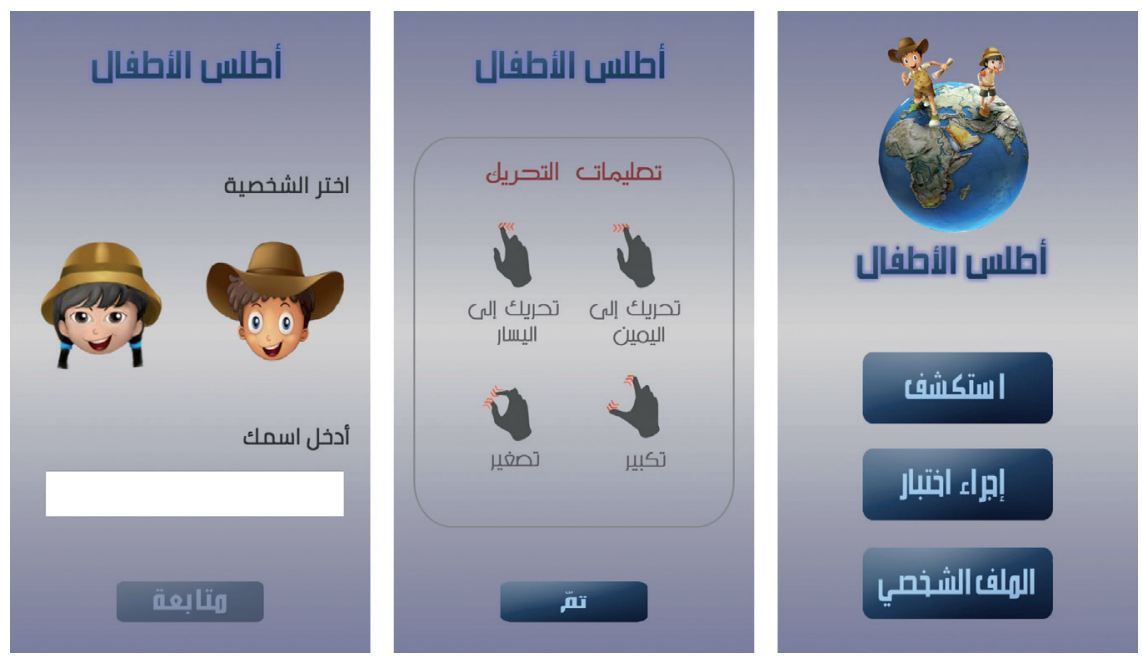

Figure 3: Interfaces of Kids Atlas.

Nahla Aljojo, Ameen Banjar, Mashael Khayyat, Basma Alharbi, Areej Alshutayri, Amani Jamal, Azida Zainol, Dana Waggas, Ghydaa Saleh, Rahaf Alshehri and Shoroug Aljuaid Kids' Atlas application to Learn about

Geography and Maps
ADCAIJ: Advances in Distributed Computing and Artificial Intelligence Journal Regular Issue, Vol. 9 N. 2 (2020), 33-48 elSSN: 2255-2863 - https://adcaij.usal.es Ediciones Universidad de Salamanca - CC BY-NC-ND 
As a summary, the finding of this project is an application that allows children to learn and enjoy geography in a fun way by:

- Support student learning process through entertainment by adding technologies that assist children to learn geography.

- Capture children's attention by using visual objects.

- Improve children interact more effectively by using 3D items.

- Increase the individual's knowledge by providing a training section that contains simple quizzes.

- Provide listening/voice recognition capability for information countries.

- The ability to search for a country by voice recognition and zooming for searched country.

\section{Conclusion and Future Work}

The result of this project is a geography learning application that assists children in learning geography. The result has shown positive indicators that improve the children' ability and knowledge in geography. Learning geography also becomes enjoyable; encouraging and motivating children to continue learning.

The Kids' Atlas application it is designed to teach children in fun and easy way. The main objective is to promote the child's culture about the countries and maps of the world, and to improve their knowledge by asking them questions. To make it more entertaining for the children, we designed a 3D object to show them the most important milestones in the world and display the information by voice in an easy and fun way for the child so that he can remember it.

A key feature of this application is it is in Arabic, which is a good addition to the Arab world. We would like to expand the application and improve it further to make it more effective and provide more functionality in the future by implementing the following:

- The strategy of being present in public and private schools. This means more advertising and marketing efforts to increase its presence in public and private schools.

- Extend the application to work on all Android devices, Apple and other systems.

- Allow the application to be accessible to everyone and downloadable from the Internet at a minimal cost or for free.

- Dissemination of the application widely within and outside the Kingdom of Saudi Arabia.

To conclude, this project has successfully developed a geography application targeting children to encourage them to learn geography with excitement. This project contributes to the growth of education in early childhood, which is essential to shape the nation for the future. Therefore, this project is significant and relevant, as it shapes the knowledge society in Saudi Arabia.

\section{References}

3D Max. (2019). Retrieved from https://www.autodesk.com/products/3ds-max/overview?support=ADVANCED $\&$ plc $=3$ DSMAX \&term $=1-$ YEAR $\&$ quantity $=1$

Adobe Illustrator. (2019). Retrieved from https://www.adobe.com/mena_en/products/illustrator.html?gclid=Cj0KCQjw17n1BRDEARIsAFDHFeys1CmfPpu2Q1q6RsPFA6ByRziugU44QqwoRTwFd-

Nahla Aljojo, Ameen Banjar, Mashael Khayyat, Basma Alharbi, Areej Alshutayri, Amani Jamal, Azida Zainol, Dana Waggas, Ghydaa Saleh, Rahaf Alshehri and Shoroug Aljuaid Kids' Atlas application to Learn about

Geography and Maps
ADCAIJ: Advances in Distributed Computing and Artificial Intelligence Journal Regular Issue, Vol. 9 N. 2 (2020), 33-48 elSSN: 2255-2863 - https://adcaij.usal.es Ediciones Universidad de Salamanca - CC BY-NC-ND 
e5YsY-z9zKBBecaAhlwEALw_wcB\&sdid=8DN85NTZ\&mv=search\&skwcid=AL!3085!3!34087 5218852 !b!!g!!\%2Badobe \%2Billustrator\&ef_id=Cj0KCQjw17

Alnahdi, G. H. (2014). Educational Change In Saudi Arabia. Journal of International Education Research (JIER), 10(1), 1-6. https://doi.org/10.19030/jier.v10i1.8342

Ambler, S. W. (2014). User Interface Design Tips, Techniques, and Principles. Retrieved from https:// www.ambysoft.com/essays/userInterfaceDesign.html

Ammann, P., \& Offutt, J. (2016). Introduction to software testing. Cambridge University Press.

Arnowitz, J., Arent, M., \& Berger, N. (2007). Effective prototyping for software makers. Elsevier.

Barefoot World Atlas Review for Teachers. (2019). Retrieved from https://www.commonsense.org/education/app/barefoot-world-atlas

Design Phase - ZMQ Development. (2019).

Elmasri, R., \& Navathe, B. S., (2010). Fundamentals of Database Systems (6th ed.). Addison Wesley Publishing Company.

GÖKÇE, N. (2009). The_Problems_of_Geography_Education_and_Some_Suggestions @ www.academia.edu. EDUCATIONAL SCIENCES: THEORY \& PRACTICE, 9(2), 757-768.

Google Forms: Online Form Builder for Business I G Suite. (2019). Retrieved from https://gsuite. google.com/intl/en/products/forms/?utm_source=google\&utm_medium $=$ cpc\&utm_campaign=emea-sa-all-en-dr-bkws-all-all-trial-e-t1-1008069\&utm_content=text-ad-none-none-DEV_cCRE_167742349370-ADGP_Hybrid \%7C AW SEM \%7C BKWS EXA_M:1_SA_EN_Forms_mi

Ian, S. (2016). Software Engineering Tenth Edition (Tenth Edit). England: Pearson Education.

Kaya, N. (2018). Main challenges in front of the teachers to teach geography more effectively: A phenomenological research. Review of International Geographical Education Online, 8(2), 371-393.

Maryland. (2009). Phase 5: Design - Custom Single Release Project.

Mclaughlin, J., \& Skinner, D. (2000). Technology Analysis \& Strategic Management Developing Usability and Utility : A Comparative Study of the Users of New IT. Technology Analysis \& Strategic Management, 12(3), 413-423. https://doi.org/10.1080/09537320050130633

Planet Geo - geography games for kids \& teenagers. (2019). Retrieved from https://www.commonsense. org/education/app/planet-geo-geography-games-for-kids-teenagers/field-notes

Prensky, M. (2002). What Kids Learn That 's POSITIVE From Playing Video Games. Learning.

Pressman, R., \& Maxim, B. (2015). SOFTWARE ENGINEERING: A PRACTITIONER'S APPROACH (8th ed.). New York: McGraw-Hill Education.

Shneiderman, B., Plaisant, C., Cohen, M., Jacobs, S., Elmqvist, N., \& Diakopoulos, N. A. (2016). Designing the User Interface: Strategies for Effective Human-Computer Interaction (6th ed.). Pearson Education.

Tiong, E., Seow, O., Teo, K., Silva, A., Wood, K. L., Jensen, D. D., \& Yang, M. C. (2018). The economies and dimensionality of prototyping: Value, time, cost and fidelity. Proceedings of the ASME Design Engineering Technical Conference, 7(August). https://doi.org/10.1115/DETC2018-85747

Top 10 Reasons to Study Geography. (2019). Retrieved October 20, 2019, from https://www.cangeoeducation.ca/resources/why_geography/top10.asp

Whitehead, C. C. (2006). Evaluating Web Page and Web Site Usability. In Proceedings of the 44th annual southeast regional conference on - ACM-SE (pp. 788-789).

Wonder Earth. (2019). Retrieved from https://apps.apple.com/us/app/wonder-earth/id1135326988

World Map Challenge! Geography. (2015). Retrieved July 2, 2019, from https://apps.apple.com/us/app/ world-map-challenge-geography/id986463559

Nahla Aljojo, Ameen Banjar, Mashael Khayyat, Basma Alharbi, Areej Alshutayri, Amani Jamal, Azida Zainol, Dana Waggas, Ghydaa Saleh, Rahaf Alshehri and Shoroug Aljuaid Kids' Atlas application to Learn about

Geography and Maps
ADCAIJ: Advances in Distributed Computing and Artificial Intelligence Journal Regular Issue, Vol. 9 N. 2 (2020), 33-48 eISSN: 2255-2863 - https://adcaij.usal.es Ediciones Universidad de Salamanca - CC BY-NC-ND 